\title{
Microscopic aspects of the colonization of Pyricularia oryzae on the rachis of wheat plants supplied with silicon
}

\author{
Maria Fernanda Antunes da Cruz ('); Larisse Arantes Freitas Silva ( $\left.{ }^{2}\right)$; \\ Jonas Alberto Rios ( $\left.{ }^{1}\right)$; Daniel Debona ('); Fabrício Ávila Rodrigues ( ${ }^{1 *}$ ) \\ (') Universidade Federal de Viçosa (UFV), Departamento de Fitopatologia, Av. Peter Henry Rolfs, s/n, 36570-900 Viçosa (MG), Brasil. \\ (2) UFV, Departamento de Biologia Vegetal, 36570-900 Viçosa (MG), Brasil. \\ (*) Corresponding author:fabricio@ufv.br
}

Received: Jan. 19, 2014; Accepted: Feb. 16, 2015

\begin{abstract}
Considering the importance of blast, caused by Pyricularia oryzae, to reduce wheat yield, this study investigate how silicon (Si) could reduce the wheat blast symptoms in the rachis tissues using light microscopy and scanning electron microscopy. Wheat plants (cv. BR 18) were grown in hydroponic culture with either 0 (-Si) or $2 \mathrm{mM} \mathrm{(+Si)} \mathrm{of} \mathrm{Si.} \mathrm{Blast} \mathrm{symptoms} \mathrm{were} \mathrm{very}$ well developed on the spikes of the -Si plants, which showed intense discoloration in contrast with the spikes of the + Si plants. At 72 hours after inoculation (hai), fungal hyphae extensively colonized the epidermis and the collenchyma tissue in the radial direction in the rachis of the -Si plants. In the +Si plants, fungal hyphae colonized the epidermis and the collenchyma cells to a lesser extent than in the -Si plants. At 96 hai, fungal hyphae were observed in the epidermis, vascular bundles and cortical tissue in the rachis node of the -Si plants. In the +Si plants, a phenolic-like material was detected in the parenchyma with lower fungal colonization in comparison with the -Si plants. In scanning electron microscopy, fungal hyphae were scarcely observed in the upper epidermal, collenchyma and parenchyma cells in the rachis tissue of the +Si plants, whereas in the rachis tissue of the -Si plants, fungal hyphae extensively colonized the epidermis, collenchyma, parenchyma and vascular bundles.
\end{abstract}

Key words: Triticum aestivum L., blast, host defense responses, mineral nutrition.

\section{INTRODUCTION}

Among the diseases affecting the yield of wheat (Triticum aestivum $\mathrm{L}$.) in Brazil, blast, caused by the hemibiotrophic fungus Pyricularia oryzae (Cooke) Sacc., is of the greatest importance. On the leaves, the symptoms of blast begin as gray-green, water-soaked lesions with dark green borders that become light tan in color with necrotic borders (Igarashi et al., 1986). Gray-brown lesions are often observed on spikes and spikelets (Goulart et al., 2007). Spike tip death and bright black spots on the rachis are often observed. The occurrence of gray-brown lesions on the spikes and spikelets significantly contributes to yield reduction due to low levels of nutrient translocation to the grains (Goulart et al., 2007).

Blast has been controlled through treatment of seeds with fungicides, the application of systemic fungicides at different plant growth stages, and the use of cultivars with high levels of resistance (Goulart et al., 2007). However, new alternative methods for disease control are necessary to avoid the yield losses that are caused by this disease worldwide. In light of these concerns, silicon (Si) shows promise as an environmentally friendly choice.
Although Si is not considered an essential nutrient for plants, it has been important in reducing the intensities of diseases in many economically important crops, such as banana, barley, beans, cucumber, oats, rice and wheat (Bélanger et al., 2003; Dallagnol et al., 2009; Fortunato et al., 2012, 2014; Polanco et al., 2012; Xavier et al., 2011). Xavier et al. (2011) showed that the incubation period of blast on the leaves of wheat plants increased with the use of $\mathrm{Si}$, whereas the area under the blast progress curve and the number of lesions per $\mathrm{cm}^{2}$ of leaf area significantly decreased. The authors reported that high concentrations of lignin-thioglycolic acid derivatives and high activities of chitinases and peroxidases contributed to the increase in wheat resistance to blast. The supply of $\mathrm{Si}$ contributed to a decrease in blast severity, in addition to improving gas exchange performance and decreasing dysfunction at the photochemical level of the Si-supplied plants (Perez et al., 2014).

To date, information in the literature regarding the effect of $\mathrm{Si}$ on the colonization process of P. oryzae in the rachis tissue of wheat is lacking. Therefore, the primary goal 
of the present study was to determine, at the microscopic level, whether Si could potentiate rachis resistance to fungus colonization.

\section{MATERIALS AND METHODS}

\section{Nutrient solution preparation}

The nutrient solution used in this study was prepared following Hoagland \& Arnon (1950) with some modifications and included the following macronutrients: $1.0 \mathrm{mM}$ $\mathrm{KNO}_{3}, 0.25 \mathrm{mM} \mathrm{NH}_{4} \mathrm{H}_{2} \mathrm{PO}_{4}, 0.1 \mathrm{mM} \mathrm{NH}_{4} \mathrm{Cl}, 0.5 \mathrm{mM}$ $\mathrm{MgSO}_{4} \cdot 7 \mathrm{H}_{2} \mathrm{O}$ and $1.0 \mathrm{mM} \mathrm{Ca}\left(\mathrm{NO}_{3}\right) \cdot 4 \mathrm{H}_{2} \mathrm{O}$; and the following micronutrients: $0.30 \mu \mathrm{M} \mathrm{CuSO}_{4} .5 \mathrm{H}_{2} \mathrm{O}, 0.33 \mu \mathrm{M}$ $\mathrm{ZnSO}_{4} .7 \mathrm{H}_{2} \mathrm{O}, 11.5 \mu \mathrm{M} \mathrm{H}_{3} \mathrm{BO}_{3}, 3.5 \mu \mathrm{M} \mathrm{MnCl}_{2} .4 \mathrm{H}_{2} \mathrm{O}$, $0.1 \mu \mathrm{M}\left(\mathrm{NH}_{4}\right) \cdot 6 \mathrm{Mo}_{7} \mathrm{O}_{2} \cdot 4 \mathrm{H}_{2} \mathrm{O}, 25 \mu \mathrm{M} \mathrm{FeSO} \cdot 7 \mathrm{H}_{2} \mathrm{O}$ and $25 \mu \mathrm{M}$ EDTA bisodium. Silicon was supplied as monosilicic acid, which was prepared by passing potassium silicate through cation-exchange resin (Amberlite IR-120B, $\mathrm{H}^{+}$form; Sigma-Aldrich, São Paulo, Brazil) (Ma et al., 2002). The $\mathrm{Si}$ rates used were 0 or $2 \mathrm{mM}$. The addition of monosilicic acid to the nutrient solution did not alter the $\mathrm{pH}$.

\section{Plant growth}

Wheat seeds from cultivar BR-18 were surface sterilized in $10 \%\left(\mathrm{v} \mathrm{v}^{-1}\right) \mathrm{NaOCl}$ for $1.5 \mathrm{~min}$, rinsed in sterilized water for 3 min and germinated on distilled water-soaked germitest paper (Fisher Scientific Co., Pittsburgh, PA) in a germination chamber at $25^{\circ} \mathrm{C}$ for six days. Germinated seedlings were transferred to plastic containers with the nutrient solution at one-half-strength and without the presence of $\mathrm{Si}$ for two days. After this period, the plants were transferred to new plastic with $5 \mathrm{~L}$ of nutrient solution prepared with or without Si. The nutrient solution, without aeration, was changed every three days. The $\mathrm{pH}$ was checked daily and maintained at approximately 5.5 using $\mathrm{NaOH}$ or $\mathrm{HCl}$ (1 M) when needed.

\section{Inoculation procedure}

An isolate of P. oryzae (UFV Po-1) obtained from the leaves of wheat plants grown at the Experimental Station of the Crop Science Department at Viçosa Federal University was used to inoculate the plants. This isolate was preserved in glass vials containing autoclaved barley seeds (Urashima $\&$ Kato 1994). Infected seeds were transferred to Petri dishes containing potato-dextrose-agar (PDA) media. After 3 days, PDA plugs containing fungal mycelia were transferred to new Petri dishes containing oat-agar media. These Petri dishes were placed in a growth chamber at $25^{\circ} \mathrm{C}$ with a 12-h photoperiod for 10 days. The mycelia that were producing conidia were carefully removed from the
Petri dishes with a brush to obtain a suspension of conidia. The plants at growth stage 65 (Zadoks et al., 1974) were inoculated with a $10^{5}$ conidia $\mathrm{mL}^{-1}$ suspension of $P$. oryzae. Gelatin $\left(1 \%\right.$, wt vol$\left.^{-1}\right)$ was added to the sterile water to aid conidial adhesion to the leaf blades. A volume of $20 \mathrm{ml}$ of the suspension was applied as a fine mist to the adaxial leaf blades of each plant until runoff, using a VL Airbrush atomizer (Paasche Airbrush Co., Chicago, IL). Following this, the plants were transferred to a mist chamber at $25 \pm 2{ }^{\circ} \mathrm{C}$ with a relative humidity of approximately $90 \pm 2 \%$ and were subjected to an initial 24-h dark period. After inoculation, the plants were maintained in a plastic mist growth chamber (MGC) inside a greenhouse for the duration of the experiments. The MGC was constructed of wood ( $2 \mathrm{~m}$ wide, $1.5 \mathrm{~m}$ high and $5 \mathrm{~m}$ long) and covered with transparent plastic $(100 \mu \mathrm{m}$ thick). The maximum natural photon flux density at plant canopy height was approximately $700 \mu \mathrm{mol} \mathrm{m}^{-2} \mathrm{~s}^{-1}$, and the temperature was $25 \pm 2{ }^{\circ} \mathrm{C}$ (day) and $20 \pm 2{ }^{\circ} \mathrm{C}$ (night). The relative humidity was maintained at $92 \pm 3 \%$ using a misting system in which the nozzles (model NEB-100, KGF Co., Sáo Paulo, Brazil) sprayed mist every $30 \mathrm{~min}$ for $15 \mathrm{~s}$ above the plant canopy. The temperature and relative humidity were measured using a thermo-hygrograph (TH-508, Impac, São Paulo, SP, Brazil).

\section{Processing the infected rachis tissue for microscopic studies}

The rachis and node fragments (approximately $5 \mathrm{~mm}^{2}$ ) with visual symptoms of blast were collected at 72, 96, 120 and 168 hours after inoculation (hai). The fragments were placed in glass vials containing $15 \mathrm{~mL}$ of fixative (2.5\% glutaraldehyde in $0.1 \mathrm{M}$ sodium cacodylate buffer, $\mathrm{pH}$ 7.2) and stored at $4^{\circ} \mathrm{C}$ for one week (Rodrigues et al., 2003).

\section{Light microscopy}

A total of 15 rachis fragments and 10 rachis node per treatment by collection time were carefully washed with $0.1 \mathrm{M}$ sodium cacodylate buffer, subsequently dehydrated through a graded alcohol series (10, 30, 50, 70, 85, 95 and 100\%) and embedded in methacrylate resin (Historesin, Leica, Nussloch, Heidelberg, Germany) (Rodrigues et al., 2003). A total of four blocks containing two rachis fragments were obtained for each treatment at each sampling time. Cross-sections that were $5 \mathrm{~mm}^{2}$ thick, obtained using a rotary microtome auto-advance model RM 2255 (Leica Microsystems Inc., Deerfield, IL, EUA), were stained with $0.05 \%$ toluidine blue ( $\mathrm{pH} 4.7$ ). A total of 25 semi-fine cuts were obtained per block, which were randomly distributed onto glass slides. The semi-fine sections were observed in a Carl Zeiss Axio Imager A1 microscope (Carl Zeiss, Germany), and the images were acquired digitally (Axio Cam HR, Carl Zeiss) and further processed with Axion Vision 4.8.1. 


\section{Processing of rachis samples for scanning electron microscopy (SEM)}

A total of 10 rachis fragments per treatment by collection time were carefully washed with sodium cacodylate buffer $(0.1 \mathrm{M})$ and post-fixed with $1 \%$ osmium tetroxide in $0.1 \mathrm{M}$ sodium cacodylate buffer $(\mathrm{pH} 7.2)$ for $2 \mathrm{~h}$ at room temperature (Rodrigues et al., 2003). The fragments were washed with the same buffer for 10 min four times and dehydrated in an ethanol series. After dehydration, the fragments were subjected to a Critical Point Dryer (CPD 020 Model, Bal-Tec, Balzers, Liechtenstein). The fragments were mounted on metal stubs with the aid of aluminum double-sided tape and coated with colloidal gold in a Sputter Coater apparatus coupled with a Freeze Drying Unit (FDU010 Model, Bal-Tec, Balzers, Liechtenstein). The fragments were examined using SEM (Leo $1430 \mathrm{VP}$ Model, Zeiss, Cambridge, UK), operating at $10 \mathrm{kV}$.

\section{Experimental design}

The experiment consisting of the two $\mathrm{Si}$ treatments (referred to as $-\mathrm{Si}$ and + Si plants) was arranged in a completely randomized design with ten replications. The experiment was repeated once. Each experimental unit consisted of one plastic plot with two plants.

\section{RESULTS}

\section{Disease assessement}

The blast symptoms were very well developed on the spikes of the-Si plants, which showed intense discoloration and awns at a $45^{\circ}$ angle (Figure 1a,c). In contrast, the spikes of the + Si plants showed greenish coloration and elliptical lesions with light brown color in the borders and gray centers (Figure 1b,d).
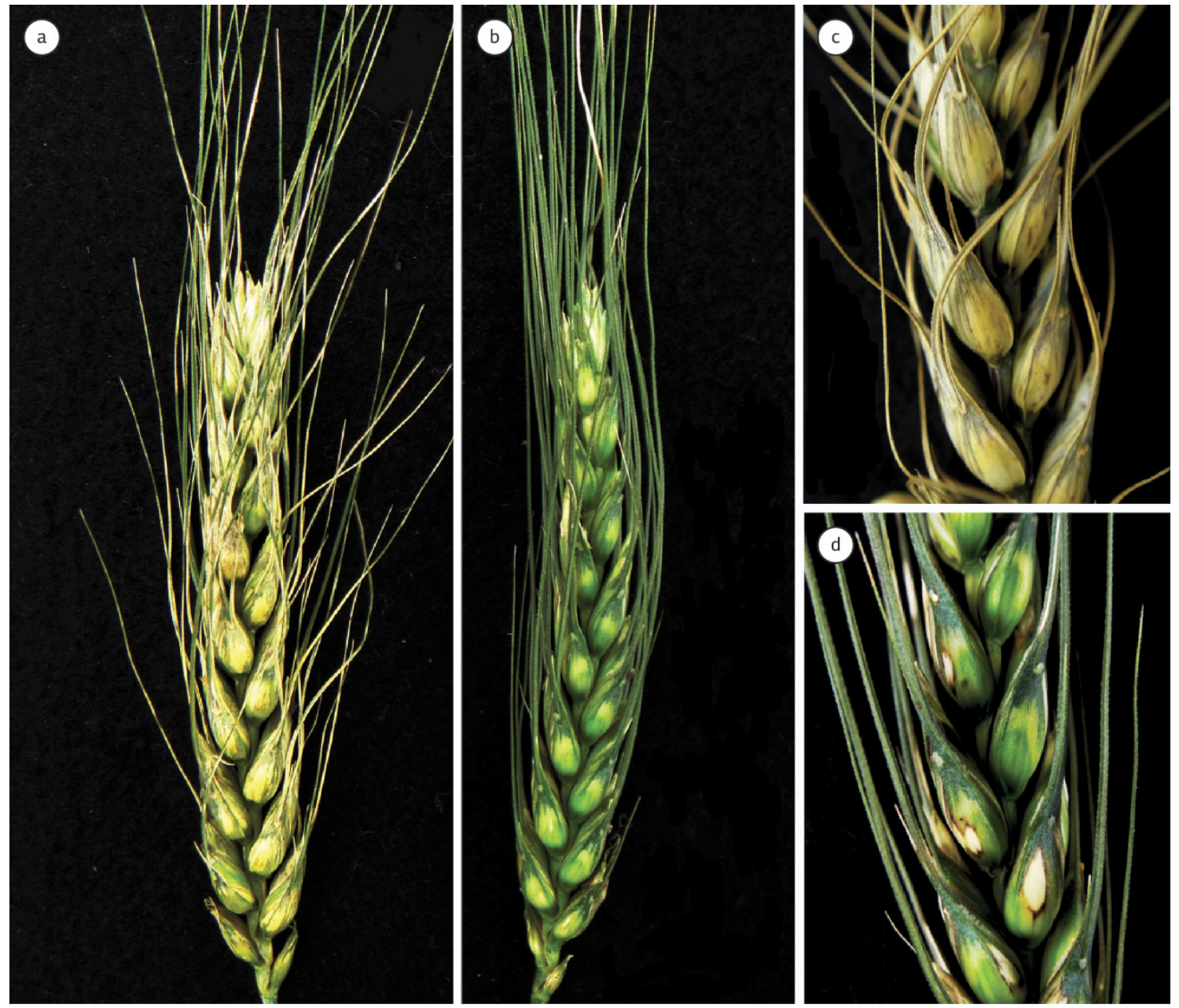

Figure 1. Symptoms of blast on the rachis of wheat plants grown in hydroponic culture containing $0(-\mathrm{Si})(\mathrm{a}$ and c) or $2 \mathrm{mM}(+\mathrm{Si})$ of silicon (b and d) at 96 hours after inoculation. 


\section{Light microscopy observations}

\section{Rachis colonization by P. oryzae}

At 72 hai, fungal hyphae reached the rachis from its node and spread upward and downward along the rachis of the $-\mathrm{Si}$ and $+\mathrm{Si}$ plants (Figure 2). Fungal hyphae grew intra- and intercellularly in the vascular bundles and in the cortical and pith parenchyma tissue of the rachis of the $-\mathrm{Si}$ and + Si plants; however, the distribution of the fungal hyphae in the rachis was not uniform (Figure 2a-h). Fungal hyphae extensively colonized the epidermis and the collenchyma tissue in the radial direction in the rachis of the -Si plants (Figure 2a-d). In the $+\mathrm{Si}$ plants, fungal hyphae colonized the epidermis and the collenchyma cells (Figure 2e-h) to a lesser extent than in the -Si plants (Figure 2a-d). The deposition of phenolic compounds was observed only for the $+\mathrm{Si}$ plants (Figure $2 \mathrm{~g}$ ). In the vascular bundles, fungal hyphae were detected in the xylem vessels, phloem sieves and cortical and pith parenchyma cells of the $-\mathrm{Si}$ and $+\mathrm{Si}$ plants (Figure 2c-f-g-h).

\section{Colonization of rachis nodes by P. oryzae}

Fungal hyphae were observed in the epidermis, vascular bundles and cortical tissue in the rachis nodes of the $-\mathrm{Si}$ plants at 96 hai (Figure 3a,b). In the vascular bundles, fungal hyphae colonized both vertical and horizontally into the xylem vessels, phloem sieves and cortical and pith parenchyma cells of the -Si plants (Figure 3a,b). In the cortical parenchyma tissue outside the vascular bundles, fungal hyphae grew both inter- and intracellularly and were able to cross the host cell wall (Figure 3a,b). In the $+\mathrm{Si}$ plants, fungal hyphae intensively colonized the epidermis and cortical parenchyma (Figure $3 \mathrm{c}, \mathrm{d}$ ), with less colonization of the xylem and phloem vessels (Figure 3d). In the rachis nodes of the + Si plants, many fungal hyphae were trapped by phenolic-like material (Figure $3 \mathrm{c}, \mathrm{d}$ ).
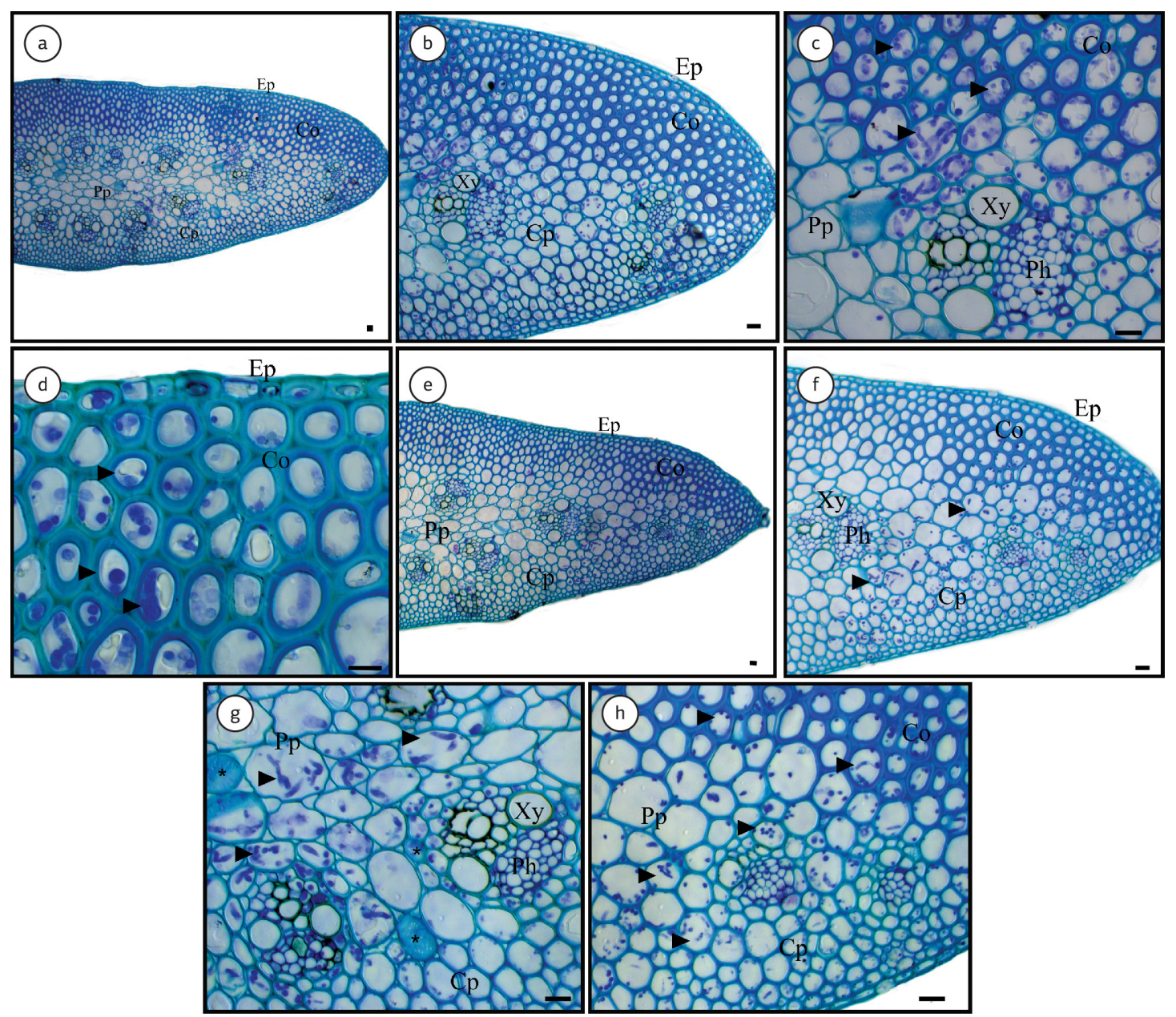

Figure 2. Light micrographs of the rachis of wheat plants grown in hydroponic culture containing $0(-\mathrm{Si})(\mathrm{a}-\mathrm{d})$ or $2 \mathrm{mM}(+\mathrm{Si})(\mathrm{e}-$ h) of silicon $(\mathrm{Si}) 72$ hours after inoculation with Pyricularia oryzae. Ep - epidermis; Co - collenchyma; Cp - cortical parenchyma; Pp parenchyma; $\mathrm{Ph}$ - phloem vessels and Xy - xylem vessels. * deposition of phenolics; arrowheads - fungal hyphae. Bars: a, b, c, d, e, f, g, $\mathrm{h}=20 \mu \mathrm{m} ; \mathrm{D}=10 \mu \mathrm{m}$. 

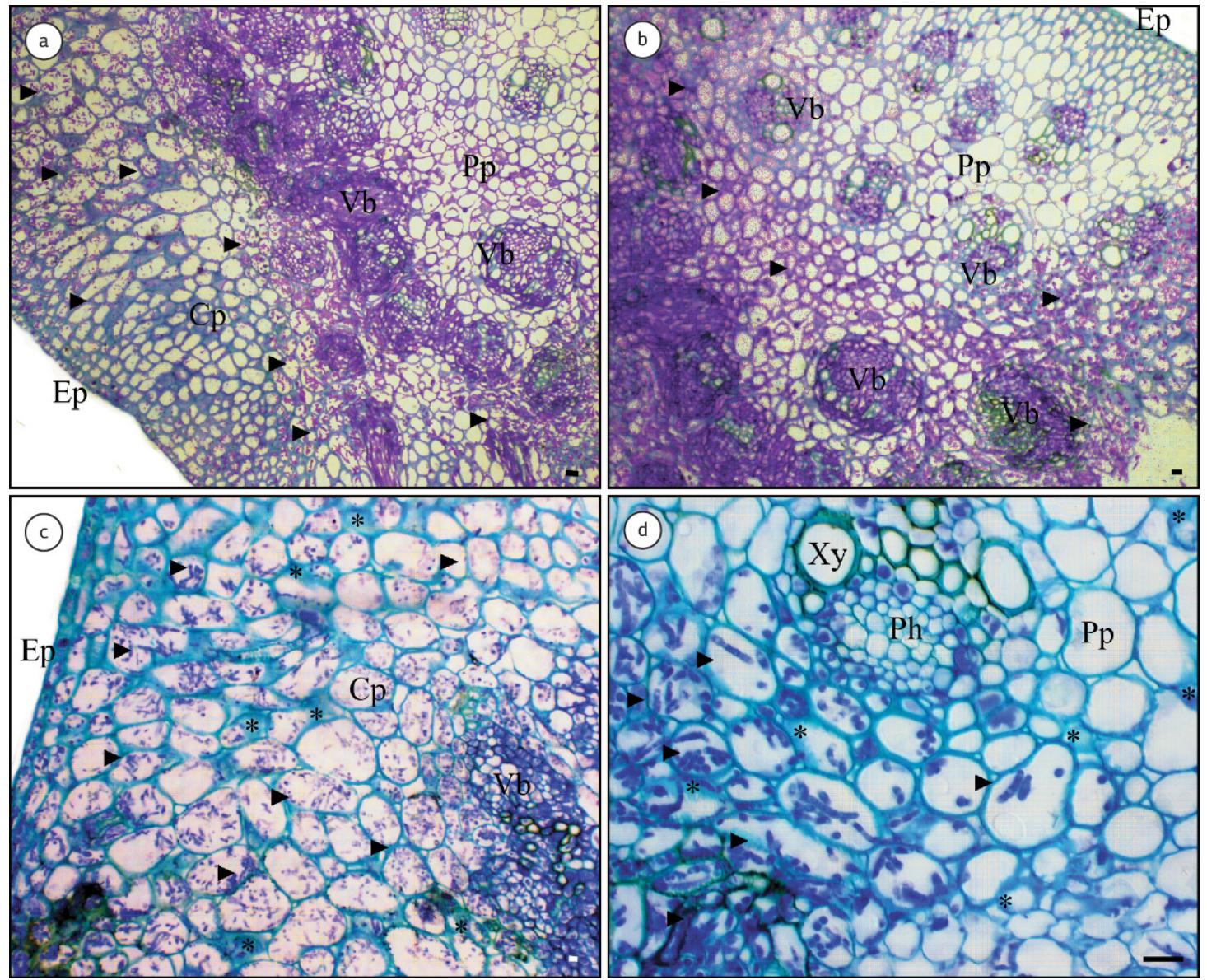

Figure 3. Light micrographs of the rachis nodes of wheat plants grown in hydroponic culture containing $0(-\mathrm{Si})(\mathrm{a}$ and $\mathrm{b})$ or $2 \mathrm{mM}(+\mathrm{Si})$ (c and d) of silicon (Si) 96 hours after inoculation with Pyricularia oryzae. Ep - epidermis; Cp - cortical parenchyma; Pp - pith parenchyma; $\mathrm{Ph}$ - phloem vessels and Xy - xylem vessels. arrowhead - fungal hyphae; * deposition of phenolics; Bars: $20 \mu \mathrm{m}$.

\section{Scanning electron microscopic observations of rachis colonization by $P$. oryzae}

In the rachis tissue of the $-\mathrm{Si}$ plants, fungal hyphae massively colonized the epidermis, collenchyma, cortical and pith parenchyma and vascular bundle at 96 hai (Figure 4a). In contrast, fungal hyphae were scarcely seem in the upper epidermal, collenchyma and cortical parenchyma cells in the rachis tissue of the $+\mathrm{Si}$ plants at 96 hai (Figure $4 \mathrm{~b}$ ). Fungal hyphae intensively colonized the xylem, phloem and parenchyma tissues of the -Si plants at 120 hai (Figure 4c). Fungal hyphae were also observed in the epidermis, collenchyma and cortical and pith parenchyma tissues of the +Si plants (Figure 4d). At 168 hai, fungal hyphae extensively colonized the xylem vessels (Figure 4e), the epidermis and the parenchyma tissues (Figure $4 \mathrm{~g}$ ) of the -Si plants. In the + Si plants, fungal hyphae were observed to a great extent in the phloem sieves (Figure 4f) but to a lesser extent in the parenchyma tissue (Figure 4h). Fungal hyphae grew both intra- and intercellularly in the vascular bundles and in the cortical parenchyma tissue of the rachis of the $-\mathrm{Si}$ and + Si plants.

\section{DISCUSSION}

To the best of the authors' knowledge, this study provides the first microscopic evidence of a reduction in P. oryzae colonization in the rachis of wheat plants supplied with $\mathrm{Si}$, where blast symptoms often occur under field conditions. Massive wheat yield losses due to blast occur when P. oryzae infects the rachis at the base of the spike, thereby limiting grain development and filling in addition to destroying the spikes completely (Goulart et al., 2007; Kohli et al., 2011). The ability of $S i$ to decrease the intensities of several diseases on many crops is well known (Datnoff et al., 2007), including blast on wheat (Debona et al., 2014; Perez et al., 2014; Rios et al., 2014; Sousa et al., 2013; Xavier et al., 2011). In rice, Datnoff et al. (1991) found reductions in both incidence and severity of neck blast on the panicles of rice plants growing in a Si-deficient Histosol amended with calcium silicate. A 40\% reduction in the incidence of neck blast on the panicles of rice plants supplied with $\mathrm{Si}$ was also reported by Seebold et al. (2004). These findings are in accordance with the results from the present study investigating wheat blast in which Si demonstrated great potential to decrease 
blast symptoms on the spikes (a visual effect) as well as on the rachis (a microscopic level observation).

A more pronounced colonization of $P$. oryzae in the rachis and rachis nodes of the $-\mathrm{Si}$ plants, possibly due to the abundance of nutrients, can greatly compromise grain filling considering the pivotal role of the rachis nodes in wheat yield. The rachis node region is rich in vascular bundles, which are responsible for nutrient and water translocation to grains to guarantee better filling. According to Goulart et al. (2007), the economic importance of wheat blast is due to yield reduction and grain quality; when infected, grains become wrinkled, small, deformed and of low weight. These authors noted that many infected spikes occurred below the strangulation of the rachis that contributed to the reduction in the number of grains and their size, in addition to the discoloration of the spikes (Goulart et al., 2007). In the present study, it was verified reduction on blast symptoms and fungal colonization in wheat rachis of + Si plants.

The cytological and molecular effects of $\mathrm{Si}$ in rice genetically defined as incompatible (resistant) or compatible (susceptible with no major resistance genes) in interaction with Pyricularia grisea were studied by Rodrigues et al. (2005) and corroborate with the results of present study. The authors verified large accumulations of glucanase, peroxidase and PR-1 transcripts that were associated with limited fungal colonization in the epidermal cells of rice plants of the susceptible cultivar when supplied with Si. In contrast, the resistant cultivar responded to an avirulent race of $P$. oryzae through the development of a hypersensitive response along with a strong induction of PR-1 and peroxidase transcripts, independent of $\mathrm{Si}$ amendment. In another study, Rodrigues et al. (2003) found the accumulation of amorphous material in the leaf tissue of rice plants supplied with $\mathrm{Si}$ and infected with P. oryzae, which resulted in the reduction of the extent of fungal colonization. In contrast, in the leaf tissue of plants not supplied with $\mathrm{Si}, P$. oryzae grew actively and colonized many epidermal and mesophyll cells. The occurrence of empty fungal hyphae surrounded or trapped in amorphous material in the leaf tissue of plants supplied with Si suggested that phenolic-like compounds or phytoalexins played a primary role in the rice defense response against infection

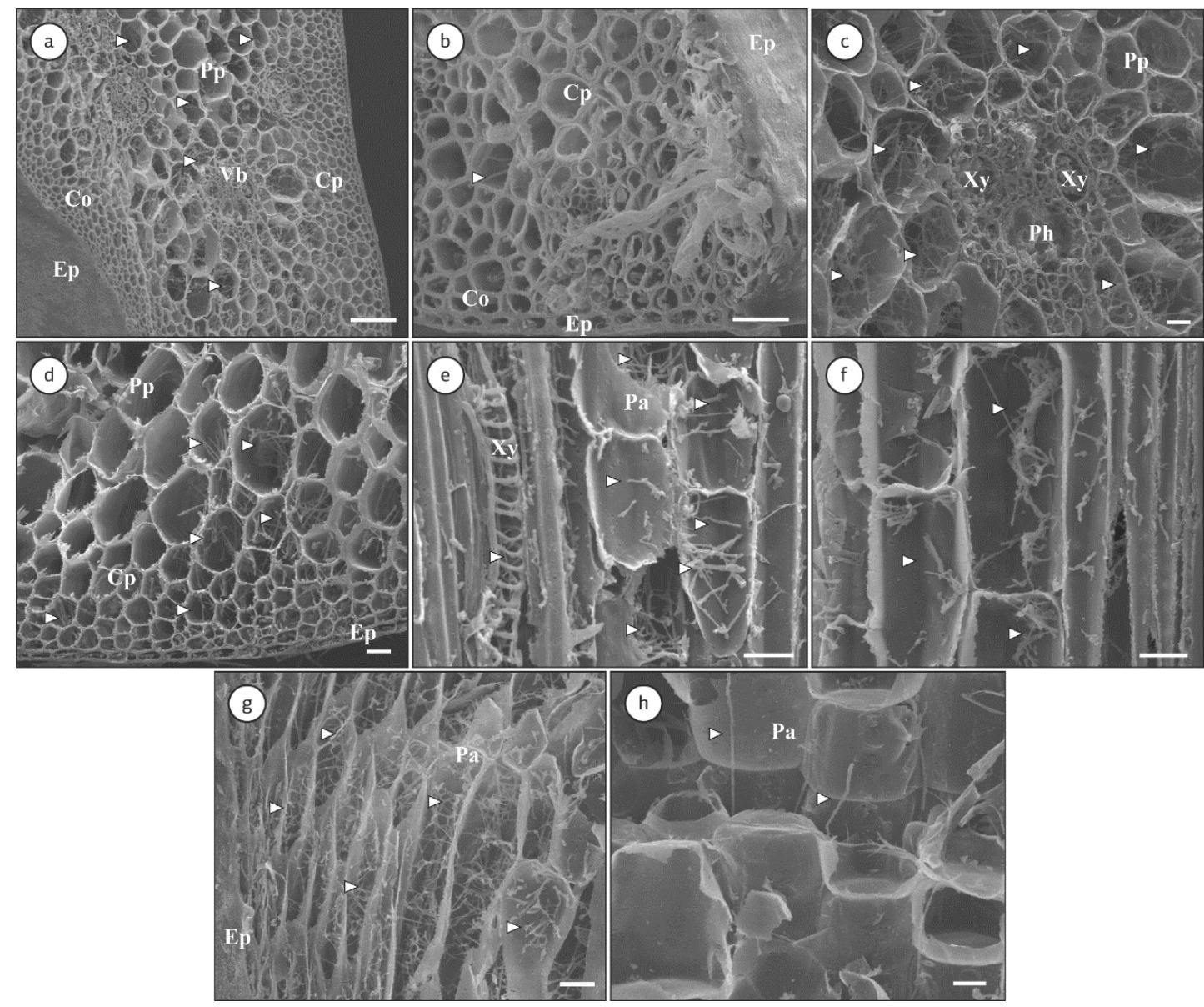

Figure 4. Scanning electron micrographs of transverse (a-d) and longitudinal (e-h) sections of the rachis of wheat plants grown in hydroponic culture containing 0 (-Si) (a, c, e and g) or $2 \mathrm{mM} \mathrm{(+Si)} \mathrm{(b,} \mathrm{d,} \mathrm{f} \mathrm{and} \mathrm{h)} \mathrm{of} \mathrm{silicon} \mathrm{(} \mathrm{Si}) 96$ (a and b), 120 (c and d) and 168 (e-h) hours after inoculation with Pyricularia oryzae. Ep - epidermis; Co - collenchyma; Cp - cortical parenchyma; Pa-parenchyma; Pp-pith parenchyma; $\mathrm{Ph}$ - phloem vessels and Xy - xylem vessels. arrowhead - fungal hyphae. Bars: $\mathrm{a}=100 \mu \mathrm{m} ; \mathrm{b}, \mathrm{e}, \mathrm{g}=30 \mu \mathrm{m} ; \mathrm{c}, \mathrm{d}, \mathrm{f}, \mathrm{h}=20 \mu \mathrm{m}$. 
by M. grisea (Rodrigues et al., 2003). Similar results were observed in the present study. Phenolic compounds were observed to a greater extent in the $+\mathrm{Si}$ plants contributing, therefore, to reduce fungal colonization.

The silicon efficiency in reduce de blast severity also was observed by Sousa et al. (2013) that examined the cytological events occurring during the infectious process of P. oryzae on the leaves of wheat plants not supplied $(-\mathrm{Si})$ or supplied $(+\mathrm{Si})$ with $\mathrm{Si}$. And observed that the high foliar $\mathrm{Si}$ concentration in the + Si plants contributed to a decrease in the blast symptoms. The hyphae of P. oryzae grew successfully and formed an extensively branched mycelium in the first-invaded epidermal cell and invaded several neighboring cells on the - Si plants, whereas on the +Si plants, the fungal hyphae were restricted to the first-invaded epidermal cell. Furthermore, the number of brown adaxial epidermal cells and their intensity of browning were significantly lower for the +Si plants, and the frequency of appressorial sites with a type $\mathrm{B}$ reaction was less for the $+\mathrm{Si}$ plants than for the $-\mathrm{Si}$ plants from 72 to 96 hours (Sousa et al., 2013). These results in wheat leaves corroborate with the data from the study using rachis, which also found intense fungal colonization from 72 hai in the - Si plants.

\section{CONCLUSION}

This study provides novel microscopic evidence that $\mathrm{Si}$ was able to increase rachis resistance against $P$. oryzae infection, and lends support to other studies of the effect of supplying Si to enhance wheat resistance to foliar pathogens. These results are of particular importance considering the key physiological role played by these parts of the wheat inflorescence in achieving increased yield.

\section{ACKNOWLEDGEMENTS}

Prof. F. A. Rodrigues thanks the CNPq for his fellowship. Dra. M. F. A. Cruz was supported by the CNPq (PDJ Scholarship, Process 503246/2012-3). The authors thank the "Núcleo de Microscopia e Microanálise" of the Universidade Federal de Viçosa" for the use of the equipments. This study was supported by grants from CAPES, CNPq and FAPEMIG to Prof. F. A. Rodrigues.

\section{REFERENCES}

Bélanger, R. R., Benhamou, N., \& Menzies, J. G. (2003). Cytological evidence of an active role of silicon in wheat resistance to powdery mildew (Blumeria graminis f.sp. tritici). Phytopathology, 93, 402-412. http://dx.doi.org/10.1094/PHYTO.2003.93.4.402. PMid:18944354
Dallagnol, L. J., Rodrigues, F. A., Mielli, M. V. B., Ma, J. F., \& Datnoff, L. E. (2009). Defective active silicon uptake affects some components of rice resistance to brown spot. Phytopathology, 99, 116-121. http:// dx.doi.org/10.1094/PHYTO-99-1-0116. PMid:19055443

Datnoff, L. E., Rodrigues, F. A., \& Seebold, K. W. (2007). Silicon and plant disease. In L. E. Datnoff, W. H. Elmer, \& D. M. Huber (Eds.), Mineral nutrition and plant disease (p. 233-246). St Paul: APS Press.

Datnoff, L. E., Snyder, G. H., Raid, R. N., \& Jones, D. B. (1991). Effect of calcium silicate on blast and brown spot intensities and yields of rice. Plant Disease, 75, 729-732. http://dx.doi.org/10.1094/ PD-75-0729.

Debona, D., Rodrigues, F. A., Rios, J. A., Nascimento, K. J. T., \& Silva, L. C. (2014). The effect of silicon on antioxidant metabolism of wheat leaves infected by Pyricularia oryzae. Plant Pathology, 63, 581-589. http://dx.doi.org/10.1111/ppa.12119.

Fortunato, A. A., Rodrigues, F. A., \& Nascimento, K. J. (2012). Physiological and biochemical aspects of the resistance of banana plants to Fusarium wilt potentiated by silicon. Phytopathology, 102, 957-966. http://dx.doi.org/10.1094/PHYTO-02-12-0037-R. PMid:22784251

Fortunato, A. A., Silva, W. L., \& Rodrigues, F. A. (2014). Phenylpropanoid pathway is potentiated by silicon in the roots of banana plants during the infection process of Fusarium oxysporum f. sp. cubense. Phytopathology, 104, 597-603. http://dx.doi.org/10.1094/PHYTO07-13-0203-R. PMid:24350769

Goulart, A. C. P., Sousa, P. G., \& Urashima, A. S. (2007). Danos em trigo causados pela infecçáo de Pyricularia grisea. Summa Phytopathologica, 33, 358-363. http://dx.doi.org/10.1590/S010054052007000400007.

Hoagland, R., \& Arnon, I. (1950). The water culture method for growing plants without soil. California Agricultural Experiment Station Circular, 347, 1-32.

Igarashi, S., Utiamada, C. M., Igarashi, I. C., Kazuma, A. H., \& Lopes, R. S. (1986). Pyricularia em trigo. 1. Ocorrência de Pyricularia sp. no estado do Paraná. Fitopatologia Brasileira, 11, 351-352.

Kohli, M. M., Mehta, Y. R., Guzman, E., De Viedma, L., \& Cubilla, L. E. (2011). Pyricularia blast: a threat to wheat cultivation. Czech Journal of Genetics and Plant Breeding, 47, S130-S134.

Ma, J. F., Tamai, K., Ichii, M., \& Wu, G. F. (2002). A rice mutant defective in Si uptake. Plant Physiology, 130, 2111-2117. http:// dx.doi.org/10.1104/pp.010348. PMid:12481095

Perez, C. E., Rodrigues, F. A., Moreira, W. R., \& DaMatta, F. M. (2014). Leaf gas exchange and chlorophyll a fluorescence in wheat plants supplied with silicon and infected with Pyricularia oryzae. Phytopathology, 104, 143-149. http://dx.doi.org/10.1094/PHYTO06-13-0163-R. PMid:24047250

Polanco, L. R., Rodrigues, F. A., Nascimento, K. J. T., Shulman, P., Silva, L. C., Neves, F. W., \& Vale, F. X. R. (2012). Biochemical aspects of bean resistance to anthracnose mediated by silicon. Annals of Applied Biology, 161, 140-150. http://dx.doi.org/10.1111/j.17447348.2012.00558.x.

Rios, J. A., Rodrigues, F. A., Debona, D., \& Silva, L. C. (2014). Photosynthetic gas exchange in leaves of wheat plants supplied with 
silicon and infected with Pyricularia oryzae. Acta Physiologiae Plantarum, 36, 371-379. http://dx.doi.org/10.1007/s11738-013-1418-3.

Rodrigues, F. A., Jurick, W. M., Datnoff, L. E., Jones, J. B., \& Rollins, J. A. (2005). Silicon influences cytological and molecular events in compatible and incompatible rice-Magnaporthe grisea interactions. Physiological and Molecular Plant Pathology, 66, 144-159. http:// dx.doi.org/10.1016/j.pmpp.2005.06.002.

Rodrigues, F. A., Vale, F. X. R., Korndörfer, G. H., Prabhu, A. S., Datnoff, L. E., Oliveira, A. M. A., \& Zambolim, L. (2003). Influence of silicon on sheath blight of rice in Brazil. Crop Protection (Guildford, Surrey), 22, 23-29. http://dx.doi.org/10.1016/S0261-2194(02)00084-4.

Seebold, K. W., Jr., Datnoff, L. E., Correa-Victoria, F. J., Kucharek, T. A., \& Snyder, G. H. (2004). Effects of silicon and fungicides on the control of leaf and neck blast in upland rice. Plant Disease, 88, 253-258. http://dx.doi.org/10.1094/PDIS.2004.88.3.253.
Sousa, R. S., Rodrigues, F. A., Schurt, D. A., Souza, N. F. A., \& Cruz, M. F. A. (2013). Cytological aspects of the infection process of Pyricularia oryzae on leaves of wheat plants supplied with silicon. Tropical Plant Pathology, 38, 472-477. http://dx.doi.org/10.1590/ S1982-56762013000600002.

Urashima, A. S., \& Kato, H. (1994). Varietal resistance and chemical control of wheat blast fungus. Summa Phytopathologica, 20, 107-112.

Xavier, M. S., Fa., Rodrigues, F. A., Domiciano, G. P., Oliveira, H. V., Silveira, P. R., \& Moreira, W. R. (2011). Wheat resistance to leaf blast mediated by silicon. Australasian Plant Pathology, 40, 28-38. http://dx.doi.org/10.1007/s13313-010-0010-1.

Zadoks, J. C., Chang, T. T., \& Konzak, C. F. (1974). A decimal code for the growth stages of cereals. Weed Research, 14, 415-421. http:// dx.doi.org/10.1111/j.1365-3180.1974.tb01084.x. 